\title{
INNOVATION IN EMERGING MARKETS: THE ROLE OF ABSORPTIVE CAPACITY AND OF THE INSERTION IN THE LOCAL AND GLOBAL VALUE CHAINS
}

\author{
CRISTINA L. L. CALEGARIO ${ }^{1}$ \\ http://orcid.org/0000-0003-2579-8744 \\ NÁDIA C. P. BRUHN ${ }^{2}$ \\ http://orcid.org/0000-0001-8607-7081 \\ MARIANE FIGUEIRA ${ }^{1}$ \\ (iD) http://orcid.org/0000-0003-4680-5608 \\ JUCIARA N. ALCÂNTARA ${ }^{1}$ \\ http://orcid.org/0000-0003-3565-9000
}

To cite this paper: Calegario, C. L. L., Bruhn, N. C. P., Figueira, M., \& Alcântara, J. N. (2019). Innovation in emerging markets: The role of absorptive capacity and of the insertion in the local and global value chains. Revista de Administração Mackenzie, 20(6). doi:10.1590/1678-6971/eRAMD 190076

Submission: Apr. 14, 2019. Acceptance: June 13, 2019.

1 Universidade Federal de Lavras (Ufla), Lavras, MG, Brazil.

2 Universidade Federal de Pelotas (UFPel), Pelotas, RS, Brazil.

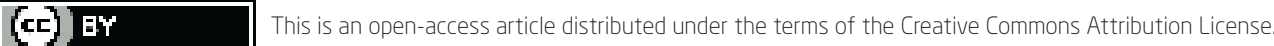

\footnotetext{
This paper may be copied, distributed, displayed, transmitted or adapted if provided, in a clear and explicit way, the name of the journal, the edition, the year and the pages on which the paper was originally published, but not suggesting that RAM endorses paper reuse. This licensing term should be made explicit in cases of reuse or distribution to third parties. It is not allowed the use for commercial purposes.

Este artigo pode ser copiado, distribuído, exibido, transmitido ou adaptado desde que citados, de forma clara e explícita, o nome da revista, a edição, o ano e as páginas nas quais o artigo foi publicado originalmente, mas sem sugerir que a RAM endosse a reutilização do artigo. Esse termo de licenciamento deve ser explicitado para os casos de reutilização ou distribuição para terceiros. Não é permitido o uso para fins comerciais.
} 


\section{ABSTRACT}

Objective: The objective of this study is to identify the effects of the insertion in local and global value chains as a determinant of company innovation, identifying the main characteristics of the nature of the interactions that arise in the value chain, as well as the relationship between innovation, internal resources to the company and their insertion in value chains.

Originality/value: This paper combines insights from different streams of literature to develop a more comprehensive framework for the analysis of firms' innovation in emerging countries. We consider relationships among partners in the local and global value chain and the influence of the internal resources as crucially important for the access to external knowledge.

Design/methodology/approach: Econometric analysis were performed using generalized linear models (GLM). The period of analysis covers the years 1998 to 2011. We investigate our hypotheses using different models to relate firms' innovation capacity to local and global value chains and the ownership of internal and external resources.

Findings: Using data from Brazilian firms from 1998 to 2011, we found that the relationship with all partners in global value chain contributed to the increase of the Brazilian firm's innovation. The internal resources had a positive influence in firm's innovation, suggesting that the firm's internal resources are crucially important in the access to external knowledge, which means that the ability of firms to make use of this knowledge depends, in turn, on their absorptive capacity.

\section{KEYWORDS}

Innovation. Value chain. Absorptive capacity. Cooperation. Generalized linear models. 


\section{INTRODUCTION}

Technological changes drive growth (Romer, 1990). Research and development $(\mathrm{R} \& \mathrm{D})$, resulting in new knowledge, new process, and new goods, it is a major source of technical progress according to the R\&D based on endogenous growth theory (Romer, 1990). As far we know, emerging countries lack growth, since firms in their markets are latecomers regarding innovativeness (Garrido, Parente, Gonçalo, \& Vasconcellos, 2017; Awate, Larsen, \& Mudambi, 2012; Li, Chen, \& Shapiro, 2010)

Given such comprehension that new technologies are fundamental for country development, attention to understand the drivers that generate technological innovation had been increasing in the academy with studies discussing the modes of innovation, the role of sources of knowledge in innovation (Lundvall, 1992; Jensen, Johnson, Lorenz, \& Lundvall, 2007) and confirmations that technical change is facilitated through reliance on inter-firm cooperation across industries (Opper \& Nee, 2015).

In this paper, we address the two different streams of literature bellow to develop a more comprehensive framework to analyze innovation in emerging countries by linking firms' innovation, cooperation in local and global chain level, and the role of a firm's internal resources to access external knowledge (Cohen \& Levinthal, 1989, 1990) in one study. There is a lack of knowledge about the joint effects of networks and firm's internal resources upon innovation (Schøtt \& Jensen, 2016), and we want to know how firms' innovation is affected by their cooperation in the value chain, but also, under the influence of their own resources.

From an analytical point of view, it is implicit a need for the study of activities taking place outside firms and, in particular, to understand the strategic role of the relationship with key external actors (Pietrobelli \& Saliola, 2008). However, we have to recognize the role of a firm's internal resources as crucially important for the access to external knowledge (Cohen \& Levinthal, 1989, 1990) and in combining both, exploiting resources from different sources. That ability to integrate knowledge residing both inside and outside the firm's boundaries is a distinctive organizational capability that develops in an organization over time (Lorenzoni \& Lipparini, 1999; Phene \& Almeida, 2008).

The organizational literature suggests that, in order to understand where innovations come from, it is important to move beyond the study of the individual entrepreneur and the firms to specify network effects in innova- 
tion activity. The importance of arrangements, such as non-price exchanges and network effects (social learning, normative influence, and network externalities) in facilitating firm-based R\&D, is beyond doubt (Opper \& Nee, 2015). Indeed, we consider that external resources per se do not ensure access and exploitation by firms. Internal resources are, therefore, drivers for accessing, exploiting and combining external knowledge (Powell, Koput, \& Smith-Doerr, 1996; Zaheer \& Bell, 2005). Then, we explore this relationship between internal and external resource in the model. In addition, we analyze different situations in which cooperation relationships are established between domestic and global partners in the value chain over time.

Considering the different streams of literature, we address the research gaps by linking firms' innovation and cooperation in the national and global chain level in a developing country in one study. This is all relevant in the presence of a developing country, as is the case of Brazil, a country with a strong import substitution background, and a well-established presence of foreign direct investors in their manufacturing sectors, making significant changes in the innovation support framework (Warwick, 2013).

The paper addresses some of the most relevant questions in this field of research, such as:

- Are there any differences between insertion in local value chain (LVC) and global value chain (GVC), as a determinant for firms' innovation?

- What are the main features of the nature of interactions arising in value chain, led by national or global suppliers/buyers?

- Is there a positive correlation between firms' innovation, their relationship in a value chain, and a firm's internal resource?

The empirical analysis is based on aggregate data from the Brazilian Innovation Survey (Pesquisa Brasileira de Inovação - Pintec - Instituto Brasileiro de Geografia e Estatística - IBGE), complemented with annual data for foreign direct investment (FDI) by sector from the Brazilian Central Bank (BCB). In order to analyze the behavior of firm innovations over time, we use all available data from Pintec surveys, corresponding to the period of 1998-2011.

The paper is organized into four sections, including this introductory one. Based on the innovativeness literature, on the local and global value chain and absorptive capacity, section 2 sets some conceptual parameters and outlines the hypotheses for the analysis. The methodological aspects are described in section 3 . Adopting this methodology, section 4 summarizes the main findings arising hereof, and the section 5 presents the concluding remarks. 


\section{THEORY AND HYPOTHESIS}

The general approach in the literature to examining the relationships between cooperation and innovation has been present in economic and management literature for a few decades, attracting much attention since the importance of innovation was recognized as conducive to building the competitive advantage of firms and, consequently, the countries. It has been well established that supporting value chains is to take advantage of their potential to increase productivity and economic growth, especially in emerging economies, where it is possible to generate economies of scale, access to new technologies and information, and to strengthen their firms (Barrientos, Gary, \& Rossi, 2011).

Research on value chain (local and global) relationships have been explored, identifying types of value chain governance, which differ according to a trilogy of attributes (Gereffi, Humphrey, \& Sturgeon, 2005); identifying the factors that determine the behavior of chain participants, and relations that are established between them, in conjunction with the environmental rules under which they operate (Singh \& Gaur, 2013).

The extant literature is very extensive, and much organizational analysis of cooperation strategies in $\mathrm{R} \& \mathrm{D}$ draws on research activities in advanced industrial economies (Powell et al., 1996; Opper \& Nee, 2015). In developed economies, besides the firm facility to be engaged in locally and globally high-level innovation agreements, there are well-specified property rights, as well as public policies interference in the market, which makes the analysis and research approaches vary greatly from the developing economies. Despite the fact that the findings of most studies generally confirm the positive relationships between innovation and cooperation, other aspects still exist justifying the current study.

\subsection{The innovative activity of firms, the linkages in the value chain and absorptive capacity}

A review of studies on links between innovation and cooperation has identified the significant innovation-related benefits derived from firms by inter-organizational networks. Once a firm begins collaborating, it develops experience at cooperation and a reputation as a partner. Over time, firms develop capabilities for interacting with other firms (Powell et al., 1996).

Firms also minimize and share the uncertainties inherent in $R \& D$, especially in high-technology industries where the technical knowledge required 
for innovations is at the frontiers of different scientific fields and entails complexities that no firm can afford to internalize in its R\&D department (Olleros \& MacDonald, 1988). Another benefit from cooperation is that firms can exercise control over market entry, getting access to new markets for their products and reducing the time-span required for innovations (Opper \& Nee, 2015; Lewandowska, Szymura-Tyc, \& Gołębiowski, 2016).

Evidence shows how firms' innovation can benefit from collaboration with diverse partners in the value chain, such as customers, suppliers, distributors and even competitors. It seems to be different for different kinds of partners (Schøtt \& Jensen, 2016; Beers \& Zand, 2014), that is, interactions with different types of partners are likely to facilitate various stages of the innovation process and vary in benefits for product and process innovation. (Schøtt \& Jensen, 2016).

Our analysis is concerned with the potential cooperation that would stem from the exploitation of complementarities between actors situated in different parts of the value chain (customers, suppliers, and competitors) and in different geographic locations (domestic and foreign). We call it LVC or value chain in home-country, when it includes relationships with customers, suppliers and competitors partners from indigenous firms that are physically located in the focal firm's home market (Prashantham \& Birkinshaw, 2015); and GVC when an indigenous firm establishes a relationship with local affiliates of MNEs, as well as actors located in a foreign country.

Traditionally, theorists have discussed how a strong local cluster of competing and complementary actors sharpen a firm's competitiveness, accelerates the innovation process, and stimulates the process of new business formations, increasing the overall strength of the cluster (Marshall, 1920; Porter, 1990).

In terms of capability-building, it is generally accepted that strong homecountry relationships have the potential to enhance competitiveness and productivity (Porter, 1990), but only when there is a dynamic cluster of leading-edge firms operating in close physical proximity (Prashantham \& Birkinshaw, 2015). Beers and Zand (2014) explain that suppliers can provide technological knowledge on the production processes of the firm while customers and universities are sources of market related and basic knowledge, respectively (Belderbos, Carree, \& Lokshin, 2004). Firms share the costs and joint profits with their suppliers in new product development and, suppliers may find new opportunities to reduce manufacturing costs by developing cost-efficient designs as well as to enhance revenues by improving 
the market adaptability of their own standardized parts and modules (Chung \& Kim, 2003).

Cooperation with suppliers or clients has as objective to pool complementary resources and access more market information. Conversely, cooperation with public institutions involves firms that draw heavily on close to science external $R \& D$ sources and have a positive impact on patenting, while vertical co-operation only impacts the introduction of new products to the market. Cooperation with rivals seems to be mostly used to share R\&D costs in high-tech sectors (Miotti \& Sachwald, 2003). However, firms in the cluster benefit from direct observation of competitors. A study developed by Nieto and Santamaria (2007) found that collaboration with suppliers, collaborators, and research organizations benefitted from innovativeness, but also found that collaboration with competitors was negative.

Considering the main results concerning the role of cooperation relationships with different partners in the value chain leads to the development of the following hypotheses:

- H1a: Cooperation to innovation with local supplier increases positively the likelihood of the firm's innovation intensity.

- H1b: Cooperation to innovation with local client increases positively the likelihood of the firm's innovation intensity.

- H1c: Cooperation to innovation with local competitors increases positively the likelihood of the firm's innovation intensity.

The integration of a firm's internal knowledge with external knowledge accessible via inter-firm cooperation strongly affects innovation performance (Zaheer \& Bell, 2005). The domestic or foreign location of the cooperation partners is also influential to the innovation activities of the firms. However, partners abroad are more embedded in separate national innovation systems than partners in the domestic market and, therefore, have access to nationspecific resources (Miotti \& Sachwald, 2003).

The debate on the suitability of two types of external knowledge sources, domestic (home-country) and foreign (host-country), has yielded mixed results, although most of the discussions are related to the firm internalization (Lewandowska et al., 2016). Numerous studies demonstrate that relationships with foreign partners provide preliminary information and contacts needed for further expansion and that those links support the development of capabilities and relational assets (Yu, Gilbert, \& Oviatt, 
2011). On the other hand, some authors underline the suitability of home country ties (Yu et al., 2011) for foreign market access, especially if the home country builds up the competitiveness of local firms and creates opportunities for innovation cooperation.

$\mathrm{R} \& \mathrm{D}$ collaboration with a foreign partner can be explained by demand and supply issues, explains Narula (2003). To the author, demand issues deal with customers and are related to adaptive research in response to specific market conditions (due to differences in customers' tastes or legal constraints). Supply issues are related to firms seeking to utilize immobile assets that are either firm or location specific. For example, partner firms can be part of specific domestic or foreign clusters where they may benefit from the supply of specialized suppliers, the availability of a specialized workforce and the advantages.

The use of external sources from foreign partners not only enhances combinatory potential, but also enables tailoring products to customer requirements. Likewise, networks help to overcome liabilities of newness and smallness in the commercialization of innovative products (Schøtt \& Jensen, 2016). Collaboration with foreign customers is expected to lead to new product innovations because of the adaptation of products to foreign customers' preferences and to improve access to new technologies and resources that can stimulate innovation (Gulati \& Singh, 1998).

After all, we can see that the expectations are slightly different with regard to ties with foreign firms, as they will typically have stronger capabilities than indigenous firms. However, learning from such entities is unlikely to find immediate application (Prashantham \& Birkinshaw, 2015). Superior innovative abilities do not transfer automatically from partner firm to subject firm. For example, Zaheer and Bell (2005) unexpectedly found, in a cross-sectional study, no direct performance effect for mutual fund companies that worked with the most innovative partners.

Relative to other inter-firm relationships, innovative technology alliances are more difficult to manage due to the complexity of technology components, the uncertainty associated with the pace and direction of technology development, and the possible conflict of interests among partnering firms (Pisano, 1989). Transferring technology knowledge across organizational boundaries requires new routines, codes, and conventions to overcome barriers to effective collaboration. Thus, experience matters in these alliances and the benefits from relationships with superior technology partners may only manifest over time (Yu et al., 2011).

Emerging and transition economies, however, do not provide such an attractive business environment, which may result in limited cooperation 
with domestic partners. Some studies indicate that, in emerging economies, strong ties with domestic partners of small and medium firms and/or young firms may be detrimental to international expansion if domestic partners are focused on the home market and have limited international experience (Prashantham \& Birkinshaw, 2015).

Although the choice of either domestic or foreign partners depends on their suitability for cooperation defined in terms of a resource base, experience in international business, innovativeness, and collaborative openness (Lewandowska et al., 2016), research shows that collaboration with foreign agents, due to globalization trends, is more conducive to innovation than collaboration with domestic partners (Fitjar \& Rodríguez-Pose, 2013), as it also helps to maximize innovation by combining knowledge drawn from different external knowledge sources. From this perspective, we conclude developing the following hypotheses:

- H2a: Cooperation to innovate with foreign suppliers strongly increases the likelihood of firms' innovation intensity.

- H2b: Cooperation to innovate with foreign customers strongly increases the likelihood of firms' innovation intensity.

- H2c: Cooperation to innovate with foreign competitors strongly increases the likelihood of firms' innovation intensity.

Literature on innovation and technology transfer has established that access is not sufficient to learn from external knowledge sources, adequate absorptive capacity being a necessary complement (Cohen \& Levinthal, 1989) and, absorptive capabilities depend on specific investment, including in particular the existence of an R\&D department and enough qualified personnel (Miotti \& Sachwald, 2003). Therefore, we consider that the role of a firm's internal resources is crucially important in the access to external knowledge. The ability of firms to make use of this knowledge depends, in turn, on their own installed knowledge base (Cohen \& Levinthal, 1990). Without prior investment in the creation of knowledge in a particular area, firms do not build the capabilities that enable them to recognize the value of externally-generated knowledge and absorb the spillovers created by other firms. (Hervas-Oliver \& Albors-Garrigos, 2009).

The literature on the spillover effects supports the premise that not all host economies have the capacity to exploit the advantages of FDI ownership because they simply do not have the absorptive capacity (Cohen \& Levinthal, 1990). For Cohen and Levinthal (1990), the absorptive capacity of companies 
represents the ability to recognize the value of new knowledge, the ability to assimilate it and to apply it, based on commercial purposes. Absorptive capacity depends largely on the technological capabilities of local firms, and their technical capability increases the probability of positive spillovers. Thus a lower technological gap between foreign and domestic firms would result in greater productivity gains.

In this paper, we support the idea that absorptive capacity is crucial to the effective exploitation of external know-how and to obtaining benefit from complementarities between internal and external resources (HervasOliver \& Albors-Garrigos, 2009). Nevertheless, collaboration with foreign agents is more conducive to innovation than local collaboration, as it also helps to maximize innovation by combining knowledge drawn from different external knowledge sources. (Fitjar \& Rodríguez-Pose, 2013). Therefore, we state that:

- H3a: Firms' internal resources (R\&D expenditure) increase the likelihood of firms' innovation.

- H3b: Firms' external resources (local and foreign groups) increase the likelihood of firms' innovation.

- H3c: The interaction of internal and external cooperation resources from local groups increases the likelihood of firms' innovation.

- H3d: The interaction of internal and external cooperation resources from foreign groups increases the likelihood of firms' innovation.

\section{METHODOLOGY}

\subsection{Sample}

To test the hypotheses, we conducted an empirical analysis using aggregate data from the Pintec (2011), complemented with annual data for FDI by sector from the BCB. In order to analyze the behavior of firms' innovation over time, we use all available data from Pintec surveys, corresponding to the periods 1998-2000, 2001-2003, 2003-2005, 2005-2008, and 2009-2011.

The conceptual and methodological reference of the Pintec survey is based on the Oslo Manual (Organização para Cooperação e Desenvolvimento Econômico, 2005) and on the European Community Statistics Workshop (Statistical Office of the European Communities - Eurostat), and the Community Innovation Survey (CIS). Following such references, the Pintec 
survey information is still concentrated in product and process innovations and is embedded in its scope the organizational innovations and marketing.

The quantitative analysis is based on anonymous firm-level microdata.

The research presents two temporal references: for most qualitative variables (product innovations and/or process related to those implemented in these three years) refers to a period of three consecutive years, i.e., 20092011; and for the quantitative variables (expenses and personnel occupied in $\mathrm{R} \& \mathrm{D}$, expenditures in other innovative activities, product innovation impact on sales and exports, etc.) refer to the final year of the reference period of the survey, i.e., 2011.

Information from $\mathrm{BCB}$ and Pintec were combined in order to develop our analysis. Although Pintec survey and $\mathrm{BCB}$ census reference is the national classification of economic activities (CNAE 2.0), the number of sectors diverges among the data sets. Because the number of sectors in the $\mathrm{BCB}$ Census is more aggregate than in Pintec survey, we have to reduce the number of sectors in those periods to combine data and conduct our analysis, based on BCB sectors.

The sample was given by the number of Brazilian firms in the surveys in the referred period per sector in the industry. The total sample of Pintec was of 70,567 firms (11,044 firms in 1998-2000; 11,337 firms in 2001-2003; 12,283 firms in 2003-2005; 16,371 firms in 2006-2008 and 17,479 firms in 2009-2011). Pintec publishes disclosed estimated results for the total population. Figure 3.1.1 provides the summary information of the sample size for all periods used in the study.

\section{(Figure 3.1.1)}

\section{SAMPLE, SECTORS, AND PERIODS}

\begin{tabular}{lcccc} 
Period & $\begin{array}{c}\text { Number of } \\
\text { sectors }\end{array}$ & $\begin{array}{c}\text { Total firms in } \\
\text { the sector }\end{array}$ & $\begin{array}{c}\text { Total firms that } \\
\text { developed innovation }\end{array}$ & $\begin{array}{c}\text { Percentage of firms that } \\
\text { developed innovation }\end{array}$ \\
\hline $2009-2011$ & 24 & 128,699 & 45,950 & 35.70 \\
\hline $2006-2008$ & 25 & 106,862 & 41,262 & 38,61 \\
\hline $2003-2005$ & 19 & 95,301 & 32,796 & 34,41 \\
\hline $2001-2003$ & 17 & 84,262 & 28,036 & 33,27 \\
\hline $1998-2000$ & 16 & 72,005 & 22,698 & 31.52 \\
\hline Total & 101 & 487,129 & 170,742 & 35,05 \\
\hline
\end{tabular}


The survey, applied to firms with more than ten employees, includes question to characterize firms' technological innovation strategies, as the importance of innovation activities, sources of information for innovation and cooperation, as well as the location of these sources of information and cooperation on whether firms have co-operated in order to innovate, meaning active participation in joint $R \& D$ and projects (contracting out is thus excluded). There are, in the questionnaire, seven variables to reflect the importance of innovation activities, 14 to reflect the importance of sources of information, and eight sources for cooperation. Still, there are, respectively, 12 and eight variables regarding the location of sources of information and cooperation.

Thus, we followed Araújo and Salermo (2015) who sought a shortening of these variables in order to: 1 . facilitate the characterization and interpretation of different technological strategies as latent constructs, such as "R\&D-driven innovation", "Formal sources innovation" and others; and 2. reduce the number of variables in the econometric model, even because many of these variables have low frequencies in the sample - for example, few firms cooperate with agents overseas, and this frequency is even lower if we break down this cooperation overseas by type of agent. Surveyed firms are active in the following extracting and manufacturing industries: 1. extracting industry; 2 . food products; 3 . beverages products; 4 . tobacco products; 5. textile products; 6 . wood products; 7 . pulp and paper product; 8 . printing and reproduction of recordings; 9 . coke and bio-fuel (alcohol and others); 10. petrochemical products; 11 . chemical products; 12 . pharmaceutical products; 13. rubber and plastic; 14 . non-metallic mineral products; 15 . iron and steel products; 16 . metallurgy; 17 . information technology; 18. electrical machinery and equipment 19 . machinery and equipment; 20 . motor vehicle, trailer, truck body automotive part; 21 . other transport equipment; 22. diverse products manufacturing; 23 . telecommunications and media equipment; 24. information technology service; 25 . R\&D activities.

\subsection{Empirical models and operationalization of variables}

We investigate our hypotheses using four models to relate: firms' innovation to local value chain and two observable control variables; firms' innovation to global value chain and two observable control variables; firms' innovation to internal and external resources and two observable control variables.

\subsubsection{Firms innovation dependent variable}

The dependent variable in the models measures the innovation performance of Brazilian firms. We choose among the available variables from Pintec 
survey to use a continuous variable, the total number of firms' innovation that, following the Oslo Manual recommendation, asks a question if a firm had a product and process innovation in the period. They consider if there was implementation of products (goods or services) or new processes or if it has substantially improved in the period. The implementation of innovation occurs when the product is placed on the market or when the process becomes operated by firm.

We could have chosen variables to measure the impact of innovation in the market, but because there are a reduced number of firms in each category, we decided to condense all of them in only one variable. Besides that, we identify innovation much more broadly than simply consisting of R\&D, an issue that is particularly important in industrializing country contexts. We include design and engineering activities, organizational changes, process innovations, and the outputs of these activities, reflecting innovations that are novel, both globally and to the firm (Marin \& Bell, 2010).

\subsubsection{Independent variables}

\subsubsection{Value chain}

We included in the model six variables regarding the local and global value chain that measures the firm's external cooperation to innovation with local partners in the home country and with foreign partners located in another country. They are: supplier, customer and competitor in Brazil and in the foreign country. The value chain encompasses the whole range of activities needed for a product or service to move through the different stages of production, from its original design through to its delivery to consumers and final disposal after use (Kaplinsky \& Morris, 2002). Firms' experience and collaboration with multiple partnerships, as suppliers, customers and competitors, help them develop effective partnering routines that mitigate local search constraints, and, thus, these improving the overall innovation performance impact of their partnership portfolio (Beers \& Zand, 2014).

We made a distinction in this model of local and global value chain in order to capture if there is any difference between the types of relations and interactions with actors from these two environments, home and foreign country, to access and acquire valuable knowledge, and consequently its innovativeness and levels of technological capability. Also, since Pintec survey makes distinction among partners (supplier, consumers and competitors) in the value chain, we consider each one as a variable. We expect that local firms linked to local firms will be less efficient in innovation activities than local relating with global firms, although both can increase innovation, since 
inter-organizational relations have been considered crucial for innovating (Boehe, 2007).

\subsubsection{Internal resources}

We measured internal resources by identifying the existing resources utilized by the firm in order to create new knowledge. The proxy variable, $\mathrm{R} \& \mathrm{D}$ Intensity, is the most common proxy for absorptive capacity in the literature. It measures essentially the amount of money that a company spends to develop new products and services each year, and possibly are able to have greater success collaborating with partners.

Although studies present that spending is not a prerequisite for innovation, in our models, the variable is assumed to influence the firm's innovation success through learning mechanisms. A firm with a high absorptive capacity is better able to cooperate with partners in the value chain, recognize external knowledge and transform information and resources from diverse knowledge sources into innovations. Then, we expect a positive impact of this variable on the dependent variable, firm innovation (Lorenzoni \& Lipparini, 1999; Phene \& Almeida, 2008).

\subsubsection{External resources}

This variable is used in the models 4 and 5 and measures the cooperation to innovation with Brazilian and Foreign groups as the active participation of the company in joint projects of $\mathrm{R} \& \mathrm{D}$ and other innovation projects with another organization (company or institute), which does not necessarily imply that the parties get immediate business benefits. The simple hiring of services of another organization, without their active collaboration, is not considered cooperation.

The issues focusing on cooperation to innovation, seeking to identify the relationships among a broad range of actors, are interconnected by channels of knowledge exchange and/or articulated in networks. The survey identifies the companies' partners in cooperation projects, the object of this and their location (state, other states, Mercosur, United States, Europe, and other countries) (Pintec, 2011).

\subsubsection{Control variables}

\subsubsection{Sector}

In order to test $\mathrm{R} \& \mathrm{D}$ intensity by sector, a dummy variable was introduced. The dummy variable indicates whether the sector to which the firm 
belongs is of a high, middle-high, middle, or low-technology level, using OECD (2011) classification. We expect a positive influence of the high-tech sector on the propensity to innovate.

\subsubsection{Size}

Most statistical studies show that the propensity to cooperate in $R \& D$ and to innovate is positively related to the size of the firm (Miotti \& Sachwald, 2003). The variable was measured by the log of the number of employees and should have a positive influence on the propensity to cooperate and to innovate, as well as the firm draws more heavily on external sources close to scientific research, including patents, universities, and research institutes.

\subsubsection{Foreign direct investment}

Data from FDI encompass firms receiving FDIs and foreign credits borrowers, as well as those having indirect foreign participation. Among the companies receiving foreign investment, only those with direct or indirect participation of non-residents in their share capital, representing at least $10 \%$ of stocks or shares with a right to vote, or $20 \%$ or more of their total capital, were required to inform. This approach is consistent, for instance, with the International Monetary Fund (IMF) definition of FDIs.

It is expected that the presence of FDI in the country could enhance the collaboration with foreign agents and help to maximize innovation by combining knowledge drawn from different external knowledge sources.

\subsection{Description of variables}

The set of dependent and independent variables is summarized in Figure 3.3.1.

(Figure 3.3.1)

VARIABLE DESCRIPTIONS AND THEIR OPERATIONALIZATION

\begin{tabular}{|c|c|c|}
\hline Variables & Description & Expected signal \\
\hline \multicolumn{3}{|c|}{ Dependent } \\
\hline Firms' innovation & $\begin{array}{l}\text { Total number of firms that had a product and process } \\
\text { innovation in the period. }\end{array}$ & \\
\hline \multicolumn{3}{|c|}{ Independent } \\
\hline Brazilian suppliers & $\begin{array}{l}\text { Number of firms with external cooperation to innovation } \\
\text { with local supplier in the home country. }\end{array}$ & Positive \\
\hline
\end{tabular}




\section{(Figure 3.3.1 (conclusion))}

VARIABLE DESCRIPTIONS AND THEIR OPERATIONALIZATION

\begin{tabular}{|c|c|c|}
\hline Variables & Description & Expected signal \\
\hline \multicolumn{3}{|c|}{ Independent } \\
\hline Brazilian customer & $\begin{array}{l}\text { Number of firms with external cooperation to innovation } \\
\text { with local customer in the home country. }\end{array}$ & Positive \\
\hline Brazilian competitor & $\begin{array}{l}\text { Number of firms with external cooperation to innovation } \\
\text { with local competitor in the home country. }\end{array}$ & Positive \\
\hline Foreign suppliers & $\begin{array}{l}\text { Number of firms with external cooperation to innovation } \\
\text { with foreign supplier located in another country. }\end{array}$ & Positive \\
\hline Foreign customer & $\begin{array}{l}\text { Number of firms with external cooperation to innovation } \\
\text { with foreign customer located in another country. }\end{array}$ & Positive \\
\hline Foreign competitor & $\begin{array}{l}\text { Number of firms with external cooperation to innovation } \\
\text { with foreign competitor located in another country. }\end{array}$ & Positive \\
\hline Brazilian group & $\begin{array}{l}\text { Number of firms that have a major cooperator group to } \\
\text { implement innovations located in the home country. }\end{array}$ & Positive \\
\hline Foreign group & $\begin{array}{l}\text { Number of firms that have a major cooperator group to } \\
\text { implement innovations located in a foreign country. }\end{array}$ & Positive \\
\hline R\&D expenses & The amount of firm's revenues spent on R\&D projects. & Positive \\
\hline FDI & Amount of FDI inflows in the Brazilian sectors. & Positive \\
\hline \multicolumn{3}{|c|}{ Control } \\
\hline Size & Log of the number of employees in the sector. & Positive \\
\hline Sector & $\begin{array}{l}\text { Dummy variable representing industry technological } \\
\text { intensity; } D=1 \text {, if the sector is high-tech intensity; } \\
D=0 \text {, otherwise }\end{array}$ & $D=1$, positive \\
\hline
\end{tabular}

Source: Elaborated by the authors.

\subsection{Methods}

The effects of variables related to the value chain and internal resources of the firms' innovation variable were analyzed using GLM analysis of variance. We performed the analysis undertaken in this study using SAS statistical software, version 8 . The GLM is useful for many modeling situations. The distribution of the dependent or response variable can be (explicitly) nonnormal, and it does not have to be continuous. 
That is the case for our dependent variable, which involves a count number of firms' innovation and we have to specify a distribution for our response variable. The dependent variable values are explained from a linear combination of predictor variables, which are associated to the dependent variable via a link function.

In the general linear model, the dependent variable values are expected to follow the normal distribution, and the link function is a simple identity function (i.e., the linear combination of values for the predictor variables is not transformed). In our study, given the count nature of the dependent variable, we have to specify a distribution for our response variable. In this case, it would be reasonable to assume that the dependent variable follows a Poisson distribution. Also, GLM regression provides techniques that specifically address modeling correlated and high-dimensional data and large data sets that contain many variables typically evidence multicollinearity issues.

The values of the parameters in the GLM are obtained by maximum likelihood estimation. Adjustment analysis in GLM is based on statistical deviance. To do so, we followed Allison's (2001) instructions. In general, the smaller the deviation value, the better the model fits the data.

Before estimating the models, a goodness-of-fit test was conducted for the dependent variable in the analyzed models. The results indicated a goodness-of-fit appropriate for the use of Poisson specification. The deviance is a measure of how well the model fits the data. If the model fits well, the observed values will be close to their predicted means, causing the terms to be small, and so the deviance to be small. For large samples, the distribution of the deviance is approximately a chi-squared with $n-p$ degrees of freedom $(d f)$, in which $n$ is the number of observations and $p$, the number of parameters. Thus, the deviance can be used directly to test the goodness of fit of the model (Hilbe, 2014). Based on that, if the value/df for the deviance and Pearson Chi-Square statistics is no more than 1, the Poisson model is adequate and fits the data very well.

\section{ECONOMETRIC RESULTS}

The results for the dependent variable, firm's innovation, indicated to our models an average deviance of 1.06 per $d f$ and provided a reasonable description of the data. So the model passes the goodness-of-fit test.

A correlation test was also conducted in order to verify the relationship degree between variables and if there were problems associated with multi- 
collinearity. The method used to measure the association degree between variables in this study was Pearson correlation coefficient. The tolerance (TOL) and variance inflation factor (VIF) were also used as complementary measures to detect multicollinearity. The results indicated no problems associated with multicollinearity in the analyzed models.

The summary of the statistics is provided in Figure 4.1. The sample means suggest that there is a large variance on Brazilian firms to generate innovations, on average, there are 1,179.27 that innovated in the period. On average, firms cooperate more with foreign groups than with Brazilian ones, but, considering partners in the supply chain, Brazilian firms cooperate more with local chain.

The amount of FDI has a greater variance through the sectors. Analyzing the sectors, we can realize that most of them are considered of low-intensity technology, what is not a surprise, since our sample is from an emergent country.

\section{(Figure 4.1)}

DESCRIPTIVE STATISTICS OF THE VARIABLES

\begin{tabular}{lrrrrr}
\hline \multicolumn{1}{c}{ Variable label } & Mean & $\begin{array}{c}\text { Standard } \\
\text { deviation }\end{array}$ & Minimum & Maximum & Variance \\
\hline Firm innovation & $1,179.27$ & $1,116.85$ & 16.40 & $5,729.44$ & $1,247,364.23$ \\
\hline Brazilian suppliers & 87.44 & 128.510 & 0 & $1,000.54$ & $16,514.88$ \\
\hline Brazilian customers & 76.19 & 95.77 & 0 & 496.37 & $9,173.58$ \\
\hline Brazilian competitors & 31.11 & 47.54 & 0 & 281.95 & $2,260.20$ \\
\hline Foreign suppliers & 12.60 & 13.31 & 0 & 69.87 & 177.19 \\
\hline Foreign customers & 4.07 & 7.05 & 0 & 65.64 & 49.72 \\
\hline Foreign competitors & 3.14 & 5.33 & 0 & 31.45 & 28.42 \\
\hline Brazilian group & 9.13 & 11.78 & 0 & 76.64 & 138.76 \\
\hline Foreign group & 13.60 & 14.19 & 0 & 70.89 & 201.29 \\
\hline R\&D expenses & $7,291.57$ & 1.142 & $3,774.8$ & $9,809.72$ & 1.305 \\
\hline Size & 12.028 & 0.931 & 9.745 & 14.261 & 0.868 \\
\hline Sector & 0.4455 & 0.4995 & 0 & 1.000 & 0.249 \\
\hline FDl & $1,487.03$ & $2,603.08$ & 0 & $19,287.39$ & $6,776,038.55$ \\
\hline
\end{tabular}




\subsection{Firms' innovation, local and global value chain and absorptive capacity}

We present our findings for the number of firm innovations in Figure 4.1.1. We analyzed the effects of the insertion in local and global value chains as a determinant of firm innovation and the relationship between innovation, internal resources, and their insertion in value chains.

Models 1 and 2 incorporate the effects of local chain and foreign chain, respectively. In models 3 e 4, with variables of interaction, we explore the relationship between internal and external resources, analyzing different situations in which cooperation relationships are established between global and domestic partners in the value chain over time. The idea was to analyze the effects in each model, instead of comparing them.

Hypotheses 1b was supported: cooperation to innovate with local customers increases the likelihood of the firms' innovation intensity positively. Local suppliers and competitors had significant but negative parameters. However, as expected in hypotheses $2 \mathrm{a}, 2 \mathrm{~b}$, and $2 \mathrm{c}$, foreign suppliers, customers, and competitors had significant and positive coefficients, indicating that the level of involvement in the global value chain positively influences innovation.

\section{(Figure 4.1.1)}

\section{RESULTS FOR GENERALIZED LINEAR MODELS REGRESSION}

\begin{tabular}{|c|c|c|c|c|}
\hline Variables & Model 1 & Model 2 & Model 3 & Model 4 \\
\hline Constant & $4.4079^{\star \star \star}(0.4125)$ & $4.2165^{\star \star \star}(0.4119)$ & $2.5498^{\star \star \star}(0.1698)$ & $3.0303^{\star \star \star}(01639)$ \\
\hline Brazilian suppliers & $-0.0021^{\star \star \star}(0.0003)$ & & & \\
\hline Brazilian customers & $0.0046^{\star \star \star}(0.0004)$ & & & \\
\hline Brazilian competitor & $-0.0015^{\star}(0.0006)$ & & & \\
\hline Foreign suppliers & & $0.0128^{\star \star \star}(0.0013)$ & & \\
\hline Foreign customers & & $0.0043^{*}(0.0024)$ & & \\
\hline Foreign competitors & & $0.0053^{\star}(0.0030)$ & & \\
\hline Brazilian group & & & $0.0037^{\star \star \star}(0.0006)$ & - \\
\hline Foreign group & & & - & $0.0257^{* \star \star}(0.0062)$ \\
\hline R\&D expenses & & & $0.0996^{\star \star \star}(0.0241)$ & $0.1041^{* \star *}(0.0260)$ \\
\hline $\begin{array}{l}\text { R\&D expenses *Brazilian } \\
\text { group }\end{array}$ & & & $-0.0003^{\star \star \star}(0.0001)$ & - \\
\hline
\end{tabular}




\section{(Figure 4.1.1 (conclusion))}

RESULTS FOR GENERALIZED LINEAR MODELS REGRESSION

\begin{tabular}{|c|c|c|c|c|}
\hline Variables & Model 1 & Model 2 & Model 3 & Model 4 \\
\hline $\begin{array}{l}\text { R\&D expenses *foreign } \\
\text { group }\end{array}$ & & & - & $0.0016^{\star}(0.0008)$ \\
\hline \multicolumn{5}{|c|}{ Control Variables } \\
\hline Size & $0.0001^{\star \star \star}(0.0001)$ & $0.0001^{\star \star \star}(0.0001)$ & & \\
\hline Sector & $-0,0926^{\star}(0.0409)$ & $-0.1372^{\star \star}(0.0422)$ & & \\
\hline FDI & & & $-0.1903^{\star \star \star}(0.0463)$ & $-0.4227^{\star \star \star}(0.0445)$ \\
\hline \multicolumn{5}{|c|}{ Goodness of fit } \\
\hline Deviance (value/df) & 1.0431 & 1.0374 & 1.0512 & 1.0620 \\
\hline
\end{tabular}

$N=101 ;{ }^{*} p<0.05 ;{ }^{* \star} p<0.01 ;{ }^{\star \star \star} p<0.001$

Source: Elaborated by the authors.

The lack of positive local suppliers and competitors' effect in model 1 may be a consequence of the lower capacity of Brazilian firms to enhance productivity and competitiveness provided by lower technological knowledge on the production processes and, although the number of local partners is larger than the foreign ones, the latter is more effective to generate innovation. We also suggest that the mean for cooperation with the local suppliers and competitors' variable is low, indicating that many firms do not have a partner with them and, if they do, it is from a lower technology intensity based on the sector mean data.

The results of estimating models 4 and 5 consider the role of the firms' internal resources as crucially important in the innovation process. In both models, Hypothesis $3 \mathrm{a}$ was supported with significant and positive coefficients, meaning the internal resources, measured by the $\mathrm{R} \& \mathrm{D}$ expenditure, were assumed to influence innovation.

Also, the cooperation with research groups, local and global, proxy variable for external resources, had the same behavior. Cooperation with partners is also influential to innovation activities of the firm. However, in our results, there was not a difference between foreign and local groups.

The interaction of a firm's internal and external resources accessible via inter-firm cooperation was captured only in model 5, in which we have considered the foreign group. We had assumed that their own installed labs with high employee levels could enable them to cooperate with foreign partners, supporting Hypothesis $3 \mathrm{~d}$. 
As for control variables, the variable size measured by the existing number of employees in each sector was positive and significant. The variable sector had also influence in the models.

Comparing the high and low-technology sectors reveals that collaboration is more effective in low-tech sectors. It seems that collaboration to make inter-firm alliances is more essential to innovations in these markets, as firms need to rely more on external resources.

The results suggest that the amount of FDI has a negative effect on firms' innovation, probably for the fact that foreign investment is concentrated in some sectors, as shown in Figure 4.1. Studies on Brazilian FDI demonstrated that higher technology sectors attract more FDI than the lower ones (Bruhn \& Calegario, 2014). Besides that, not all host economies have the capacity to exploit the advantages of FDI due to the fact they simply do not have the absorptive capacity to do so (Cohen \& Levinthal, 1990).

\section{CONCLUDING REMARKS}

The results of this study indicate that the relationship with all partners in the global value chain (suppliers, customer, and competitors) contributed to increase the Brazilian firm's innovation. In the local value chain, only the relationship with customer partners presented the same results. Evidence shows that interactions with different types of partners are likely to produce a distinct effect on the innovation capacity of local firms. These results suggest that the integration of a firm's internal knowledge with external knowledge accessible via inter-firm cooperation strongly affects innovation. It is expected that the use of external sources of knowledge from foreign partners enables tailoring products to customer requirements and that networks help to overcome liabilities of newness and smallness in the commercialization of innovative products.

The internal resources had positive influence on firms' innovation. The role of a firm's internal resources is also crucially important in the access to external knowledge, which means that the ability of firms to make use of this knowledge depends, in turn, on their own installed knowledge base and absorptive capacity, which enables them to recognize the value of externallygenerated knowledge and to absorb the spillovers created by other firms.

Contrary to expectations, the results indicate that FDI has not contributed to the innovative performance of local firms. The literature on the spillover effects supports the premise that not all host economies have 
the capacity to exploit the advantages of FDI ownership because they simply do not have the absorptive capacity. The beneficial effects of FDI occur only if firms from the home economies have the capacity to assimilate and apply new knowledge.

Superior innovative abilities do not transfer automatically from partner firm to subject firm. Innovative technology alliances are more difficult to manage, due to the complexity of technology components, the uncertainty associated with the pace and direction of technology development, and the possible conflict of interests among partnering firms. Transferring technology knowledge across organizational boundaries requires new routines, codes, and conventions to overcome barriers to effective collaboration. Thus, experience matters in these alliances and the benefits from relationships with superior technology partners may only manifest over time.

Some limitations of this study are worth mentioning, which render several promising research avenues. First, this study relies on publicly available data, but even more insightful inferences could be drawn from a dedicated survey, used in combination with interviews with managers. Second, the dataset imposed some restrictions on our analysis, and some more disaggregated analyses that could be interesting are not possible to conduct.

Innovation in emerging markets firms is a recent phenomenon, about which we have limited understanding. Our empirical investigation offers support to identify the effects of the insertion in the local and global value chains as a determinant of firms' innovation, as well as to suggest that firms' internal resources are crucially important in the access to external knowledge, which means that the ability of firms to make use of this knowledge depends, in turn, on their absorptive capacity.

\section{INOVAÇÃO EM MERCADOS EMERGENTES: O PAPEL DA CAPACIDADE DE ABSORÇÃO E DA INSERÇÃO EM CADEIAS DE VALOR LOCAL E GLOBAL}

\section{$\int$ RESUMO}

Objetivo: O objetivo deste estudo é identificar os efeitos da inserção em cadeias de valor globais ou locais como um determinante para a inovação 
da firma em países emergentes, bem como a relação existente entre capacidade de absorção e inserção em cadeias de valor.

Originalidade/valor: Este artigo combina contribuições de diferentes correntes de literatura para desenvolver uma estrutura mais abrangente sobre a análise da inovação em firmas de países emergentes. O estudo considera as relações entre os parceiros na cadeia de valor local e global, bem como a influência dos recursos internos como crucial para o acesso ao conhecimento externo.

Design/metodologia/abordagem: As análises econométricas foram feitas usando modelos lineares generalizados. O período de análise compreende os anos de 1998 a 2011. As hipóteses de pesquisa foram testadas utilizando diferentes modelos para relacionar a capacidade de inovação das empresas à inserção em cadeias de valor locais e globais ou à posse de recursos internos e externos.

Resultados: Os resultados deste estudo indicam que o relacionamento com todos os parceiros na cadeia de valor global contribui para aumentar os níveis de inovação das empresas pesquisadas. Os recursos internos tiveram influência positiva sobre a capacidade de inovação das empresas, sugerindo que os recursos internos são de importância crucial no acesso ao conhecimento externo, o que significa que a capacidade das empresas de utilizar esse conhecimento depende, fundamentalmente, de sua capacidade de absorção.

\section{PALAVRAS-CHAVE}

Inovação. Cadeia de valor. Capacidade de absorção. Cooperação. Modelos lineares generalizados.

\section{REFERENCES}

Allison, P. D. (2001). Logistic regression using SAS Systems: Theory and applications (2nd ed.). Cary, NC: SAS Institute.

Araújo, B. C., \& Salerno, M. S. (2015). Technological strategies and learningby-exporting: The case of Brazilian manufacturing firms, 2006-2008. International Business Review, 24(1), 725-738. 
Awate, S., Larsen, M. M., \& Mudambi, R. (2012). EMNE catch-up strategies in the wind turbine industry: Is there a trade-off between output and innovation capabilities? Global Strategy Journal, 2, 205-223. doi:10.1111/ j.2042-5805.2012.01034.x

Barrientos, S., Gary, G., \& Rossi, A. (2011). Economic and social upgrading in global production networks: a new paradigm for a changing world. International Labour Review, 150(3-4), 299-319.

Beers, V., \& Zand, F. (2014). R\&D cooperation, partner diversity, and innovation performance: an empirical analysis. Journal of Productive Innovation Management, 31 (2), 292-312.

Belderbos, R., Carree, M., \& Lokshin, B. (2004). Cooperative R\&D and firm performance. Research Policy, 33, 1477-1492.

Boehe, D. M. (2007). Os papéis de subsidiárias brasileiras na estratégia de inovação de empresas multinacionais estrangeiras. Revista Eletrônica de Administração, 42(1), 5-18.

Bruhn, N. C. P., \& Calegario, C. L. L. (2014). Productivity spillovers from Foreign Direct Investment in the Brazilian processing industry. Brazilian Administration Review, 11 (1), 22-46.

Chung, S., \& Kim, G. M. (2003). Performance effects of partnership between manufacturers and suppliers for new product development: The supplier's standpoint. Research Policy, 32 (1), 587-603.

Cohen, W., \& Levinthal, D. (1989). Innovation and learning: The two faces of R\&D. Economic Journal, 99(1), 569-596.

Cohen, W., \& Levinthal, D. (1990). Absorptive capacity: A new perspective on learning and innovation. Administrative Science Quarterly, 35, 128-152.

Fitjar, R. D., \& Rodríguez-Pose, A. (2013). The geographical dimension of innovation collaboration: Networking and innovation in Norway. Urban Studies, 51, 2572-2595.

Garrido, I. L., Parente, R. C., Gonçalo, C. R., \& Vasconcellos, S. L. de. (2017). Remaining innovative: The role of past performance, absorptive capacity, and internationalization. Brazilian Business Review, 14(6), 559-574. doi:10. 15728/bbr.2017.14.6.1

Gereffi, G., Humphrey, J., \& Sturgeon, T. (2005). The governance of global value chains. Review of International Political Economy, 12 (1), 78-104. doi:10. 1080/09692290500049805

Gulati, R., \& Singh, H. (1998). The architecture of cooperation: Managing coordination costs and appropriation concerns in strategic alliances. Administrative Science Quarterly, 43, 781-814. 
Hervas-Oliver, J. L., \& Albors-Garrigos, J. (2009). The role of the firm's internal and relational capabilities in clusters: When distance and embeddedness are not enough to explain innovation. Journal of Economic Geography, 9(2), 263-283. doi:10.1093/jeg/lbn033

Hilbe, J. (2014). Poisson regression. In J. Hibe. Modeling count data (pp. 35-73). Cambridge: Cambridge University Press. doi:10.1017/CBO978113923 6065.003

Jensen, M. B., Johnson, B., Lorenz, E., \& Lundvall, B. A. (2007). Forms of knowledge and modes of innovation. Research Policy, 36(5), 680-693. doi:10.1016/j.respol.2007.01.006

Kaplinsky, R., \& Morris, M. (2002). A handbook for value chain research. Paper prepared for the IDRC. Retrieved from www.fao.org/fileadmin/ user_upload/fisheries/docs/Value_Chain_Handbool.pdf

Lewandowska, M. S., Szymura-Tyc, M., \& Gołębiowski, T. (2016). Innovation complementarity, cooperation partners, and new product export: evidence from Poland. Jornal of Business Research, 69(9), 3673-3681.

Li, J., Chen, D., \& Shapiro, D. M. (2010). Product innovations in emerging economies: The role of foreign knowledge access channels and internal efforts in Chinese firms. Management \& Organization Review, 6(2), 243-266. doi:10.1111/j.1740-8784.2009.00155.x

Lorenzoni, G., \& Lipparini, A. (1999). The leveraging of inter-firm relationships as a distinctive organizational capability: A longitudinal study. Strategic Management Journal, 20, 317-338.

Lundvall, B. A. (1992). National systems of innovation: Towards a theory of innovation and interactive learning. London: Pinter.

Marin, A., \& Bell, M. 2010. The local/global integration of MNC subsidiaries and their technological behavior: Argentina in the late 1990s. Research Policy, 39(7), 919-931.

Marshall, A. (1920). Principles of economics. London: Macmillan.

Miotti, L., \& Sachwald, F. (2003). Cooperative R\&D: Why and with whom? An integrated framework of analysis. Research Policy, 32, 1481-1499.

Narula, R. (2003). Globalization and technology: Interdependence, innovation systems and industrial policy. Cambridge, UK: Polity Press.

Nieto, M. J., \& Santamaria, L. (2007). The importance of diverse collaborative networks for the novelty of product innovation. Technovation, 27(6-7), 367-377. 
Olleros, F., \& MacDonald, R. J. (1988). Strategic alliances: Managing complementarity to capitalize on emerging technologies. Technovation, 7 , 155-176.

Opper, S., \& Nee, V. (2015). Network effects, cooperation and entrepreneurial innovation. Asian Business \& Management, 14(4), 283-302.

Organisation for Economic Co-operation and Development (2011). Economic Analysis and Statistics Division. OECD.

Organização para Cooperação e Desenvolvimento Econômico (2005). Manual de Oslo: Diretrizes para coleta e interpretação de dados sobre inovação (3a ed.). Brasília: Finep.

Pesquisa de Inovação Tecnólogica. (2011). Pesquisa de Inovação do IBGE. Retrieved from: https://sidra.ibge.gov.br/pesquisa/pintec/tabelas

Phene, A., \& Almeida, P. (2008). Innovation in multinational subsidiaries: The role of knowledge assimilation and subsidiary capabilities. Journal of International Business Studies, 39(5), 901-919.

Pietrobelli, C., \& Saliola, F. (2008). Power relationships along the value chain: Multinational firms, global buyers and performance of local suppliers. Cambridge Journal of Economics, 32, 947-962. doi:10.1093/cje/ben016.

Pisano, G. (1989). Using equity participation to support exchange: Evidence from the biotechnology industry. Journal of Law Economics and Organization, 5(1), 109-126.

Porter, M. (1990). New global strategies for competitive advantage. Planning Review, 18(3), 4-14.

Powell, W. W., Koput, K. W., \& Smith-Doerr, L. (1996). Interorganizational collaboration and the locus of innovation: Networks of learning in biotechnology, Administrative Science Quarterly, 41(1), 116-145. doi:10.2307/ 2393988

Prashantham, S., \& Birkinshaw, J. (2015). Choose your friends carefully: Home-country ties and new venture internationalization. Management International Review, 55(1), 207-234.

Romer, P. (1990). Endogenous technological change. Journal of Political Economy, 98(5), S71-S102.

Schøtt, T., \& Jensen, K. W. (2016). Firms' innovation benefiting from networking and institutional support: A global analysis of national and firm effects. Research Policy, 45, 1233-1246. doi:10.1016/j.respol.2016. 03.006 
Singh, D. A., \& Gaur, A. S. (2013). Governance structure, innovation and internationalization: Evidence from India. Journal of International Management, 19(3), 300-309.

Warwick, K. (2013). Beyond industrial policy: Emerging issues and new trends. OECD Science, Technology and Industry Policy Papers, (2). doi:10.17 87/5k4869clw0xp-en

Yu, J., Gilbert, B. A., \& Oviatt, B. M. (2011). Effects of alliances, time, and network cohesion on the initiation of foreign sales by new ventures. Strategic Management Journal, 32(1), 424-446.

Zaheer, A., \& Bell, G. G. (2005). Benefiting from network positions: Firm capabilities, structural holes, and performance. Strategic Management Journal, $26,809-825$.

\section{AUTHOR NOTES}

Cristina L. L. Calegario, College of Agricultural \& Environmental Science, University of Georgia (UGA); Nádia C. P. Bruhn, Programa de Pós-Graduação em Administração, Universidade Federal de Lavras (Ufla); Mariane Figueira, Programa de Pós-Graduação em Administração, Universidade Federal de Lavras (Ufla); Juciara N. Alcântara, Programa de Pós-Graduação em Administração, Universidade Federal de Lavras (Ufla).

Cristina L. L. Calegario is now associate professor at the Departamento de Administração e Economia of Universidade Federal de Lavras (Ufla); Nádia C. P. Bruhn is now professor at the Centro de Integração do Mercosul of Universidade Federal de Pelotas (UFPel); Mariane Figueira is now post doctoral researcher at the Programa de Pós-Graduação em Administração of Universidade Federal de Lavras (Ufla); and Juciara N. Alcântara is now professor at the Programa de Pós-Graduação em Administração of Universidade Federal de Lavras (Ufla).

Correspondence concerning this article should be addressed to Nádia C. P. Bruhn, Rua Andrade Neves, 1529, Centro, Pelotas, Rio Grande do Sul, Brazil, CEP 96020-080.

E-mail: nadiacpereira@yahoo.com.br

\section{EDITORIAL BOARD}

Editors-in-chief

Janette Brunstein

Silvia Marcia Russi de Domênico

Associated Editor

Carlos Ricardo Rossetto

Technical Support

Vitória Batista Santos Silva

\section{EDITORIAL PRODUCTION}

Publishing Coordination

Jéssica Dametta

Language Editor

Daniel de Almeida Leão

\author{
Layout Designer \\ Emap \\ Graphic Designer \\ Libro
}

